\begin{tabular}{|l|l|l|l|}
\hline Eiszeitalter und Gegenwart & Band 14 & Seite 96-103 & Öhringen/Württ., 1. September 1963 \\
\hline
\end{tabular}

\title{
Notes on some Pleistocene mammal migrations from the Palaearctic to the Nearctic
}

\author{
Von BJöRn KuRTÉn, Helsingfors \\ Mit 2 Abbildungen im Text
}

Summary. The following dates for mammalian migrations from the Palaearctic to the Nearctic are suggested: Smilodontine sabre-tooths, Elster (Kansan); black bears, Elster (Kansan); brown and grizzly bears, Würm (Wisconsin); wolverine, Saale (Illinoian). Correlation between the mammalian faunas in the Nearctic and the Palaearctic should be based on compilation of many additional migration items.

$\mathrm{Z} u s$ a m m e $\mathrm{f}$ as s u $\mathrm{ng}$. Die Einwanderungen einiger paläarktischer Säugetiere ins Nearktikum werden folgendermaßen datiert: Smilodontine Säbelzahnkatzen Elster (Kansan). Schwarzbären Elster (Kansan). Braunbären, bzw. Grizzlybären Würm (Wisconsin). Vielfraß Saale (Illinoian). Für eine befriedigende Korrelation zwischen den eiszeitlichen Säugetierfaunen des nearktischen und paläarktischen Raumes müßten noch eine Reihe von Einwanderungsbeispie!en analysiert werden.

The correlation between the Pleistocene mammalian faunas of North America and Europe is at present a topic of much informal discussion and controversy, but on which relatively little has been published. The knowledge of Pleistocene faunal evolution in both areas is still incomplete, more so in the Nearctic, but a fairly coherent succession has recently been worked out by HibBard and his associates (HibBard, 1958; TAYLOR \& HibBard, 1959) and related to the standard glacial-interglacial sequence. Perhaps it may still be said that knowledge is too incomplete to permit a stage-by-stage correlation on faunal evidence. Nevertheless the topic is of such interest that contributions to it should be welcomed. It appears to the present writer that the most hopeful method to attack the problem is the detailed study of case histories of intercontinental migration by means of taxonomic and evolutionary analysis. Hence I have chosen to offer some notes on a number of Carnivora, summarized from a comparative study in progress. They are intended to supply some preliminary correlation items of the desired kind. It may perhaps be hoped that specialists on this and other groups would analyse other instances of intercontinental migration in the Pleistocene, of which many would be available.

It may be assumed that migration between the Old and the New World occurred exclusively across the Bering Strait, as far as the mammals are concerned, and that it took place only when there was a land bridge; that is to say, during a glacial phase. Immigrants are therefore assumed to have migrated in the preceding cold phase, if their first occurrence is in an interglacial fauna. First occurrence in a cold fauna is taken to signify an immigration during the same cold phase. In either case, however, it is a prerequisite that a probable ancestor should be known to have existed, at the given time, in the area of assumed origin.

Errors are bound to arise sometimes because our knowledge is incomplete and later discoveries may reveal that the immigrant was actually present at an earlier date. A more detailed analysis of the evolving populations may help us to avoid errors of this kind. If it can be shown that the assumed ancestor and the immigrant form an essential morphological continuum, this may be taken as additional indication that the correct time of migration has been found. A morphological gap between the two will suggest that part of the evolutionary sequence is missing and may have taken place in either area. I have endeavoured to pay full attention to this factor in the examples to follow. 


\section{A. Sabre-tooths of the genera Megantereon and Smilodon}

The close relationship between the European Megantereon and the American Smilodon was recognized by SCHAUB (1925). Unfortunately, however, MATTHEw (1929) made the error of synonymizing the European Homotherium with Smilodon. With the discovery of excellent material of the sabre-tooth Dinobastis in the late Pleistocene of Texas (MEADE, 1961) it has become clear that this form, not Smilodon, is the American ally of the European Homotherium, whereas Megantereon is allied to Smilodon. They form two quite distinct groups of sabre-toothed cats, which may be termed the tribes Homotheriini and Smilodontini.

Schaub (1925) pointed to the detailed similarity in the postcranial skeletons of Megantereon and Smilodon. The neck, for instance, is much elongated, and the distal segments of the heavy limbs are shortened. In the Homotheriini the neck is less elongated and the limbs are not shortened distally, indeed the forearm is extremely long. The dentitions and skulls (fig. 1) are also quite distinctly constructed in the two groups. The Smilodontini have dirk-like, very long upper canines, which were evidently used for stabbing exclusively; they are relatively and absolutely larger in Smilodon, but this is only a specialized character and does not obscure the essential similarity. The lower canines were reduced and form flanking elements in the transverse incisor row. The cheek teeth are not much modified from the normal feline type, except for a progressive reduction of the anterior elements and of the protocone (internal cusp) in the upper carnassial. The skull profile tends to be triangular, with a high occiput, only slightly overhanging the occipital condyles. The post-orbital processes are well set off with a marked constriction behind, separating them from the small but globular braincase. The development of the mastoid processes is correlated with that of the head depressors and is more pronounced in the advanced Smilodon with its enormous sabres.

In contrast, the Homotheriini have relatively short, flattened sabres with crenulated, sharp cutting edges all along the front and back; wear facets show that they were used in biting, as well as stabbing and slashing. The incisors form a semicircle, unlike the
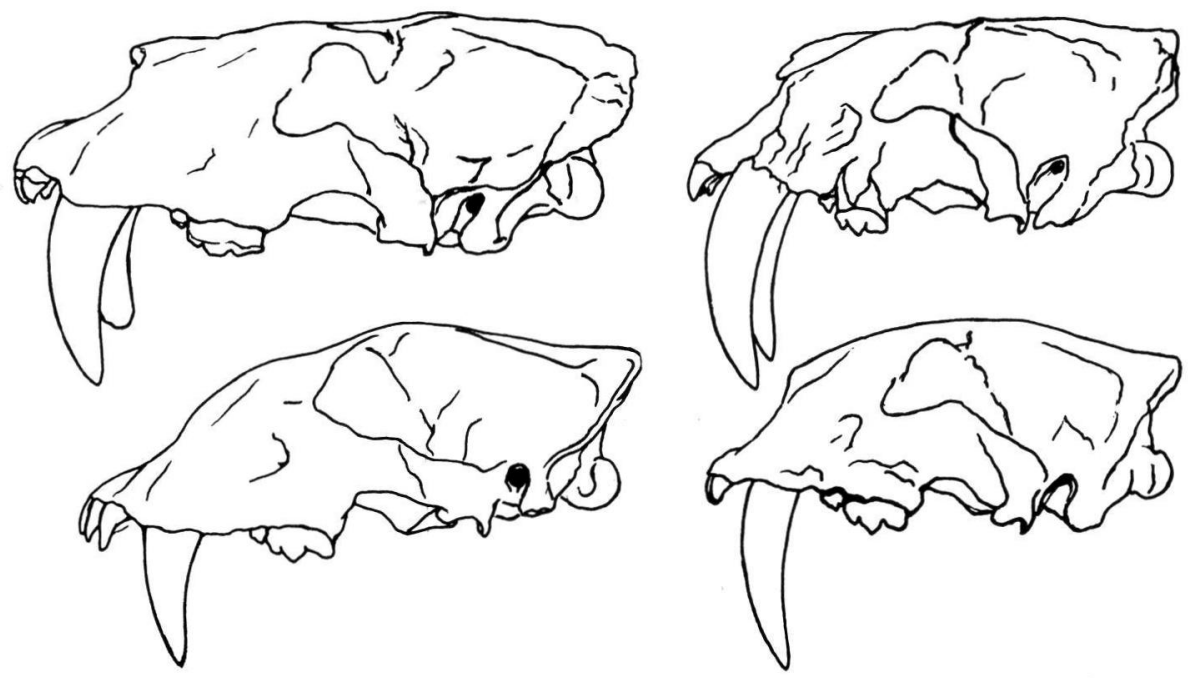

Fig. 1. Skulls of Homotheriini (left) and Smilodontini (right) in side view. Upper left, Homotherium crenatidens, Perrier, Villafranchian. Lower left, Dinobastis serus, Friesenhahn (Texas), Wisconsin. Upper right, Smilodon neogaeus, Arroyo Pergamino (Argentina), Pampean. Lower right, Megantereon megantereon, Senèze, Villafranchian. Not to scale. 
smilodont transverse row. The cheek teeth are highly modified, extremely thin slicing blades. The skull is long and low with an arched profile, the frontal region is broad without distinctly set off processes, and the braincase is separated from the occipital plane by a marked constriction.

The two tribes probably arose independently from orthodox feline cats by divergent evolution along quite different adaptive paths. The first stage in the development of sabre-like upper canines is seen in the present-day Felis nebulosa. The idea of an iterated evolution of sabre-toothed cats gains in credibility from the fact that independent evolution of sabre-toothed carnivores has been demonstrated in the Marsupialia and Creodonta.

The history of both groups is mainly or entirely contained in the Pleistocene (including the Villafranchian), and most or all of the Eurasian and American Pleistocene sabre-tooths may be referred to one group or the other.

The two main types of homotheres, Homotherium and Dinobastis, occur in both hemispheres. The former are only early Pleistocene (Villafranchian) in Europe, but may occur later in America (Ischyrosmilus?). The latter are middle and late Pleistocene (Dinobastis serus, North America; Dinobastis latidens, Europe; Dinobastis ultimus, China).

The smilodont cats show a more definite evolutionary trend and indicate an intercontinental migration at a rather narrowly defined point in time.

All the Eurasian forms are referred to the genus Megantereon. The earliest forms, apart from some possible Indian ancestors in the Pliocene, occur in the earliest Villafranchian in Europe (Villafranca d'Asti, Etouaires). They are relatively small, of perhaps puma size. There is evidence of a gradual size increase, and the late Villafranchian forms (Senèze, Val d'Arno, Nihowan) are somewhat larger. All of the European Villafranchian

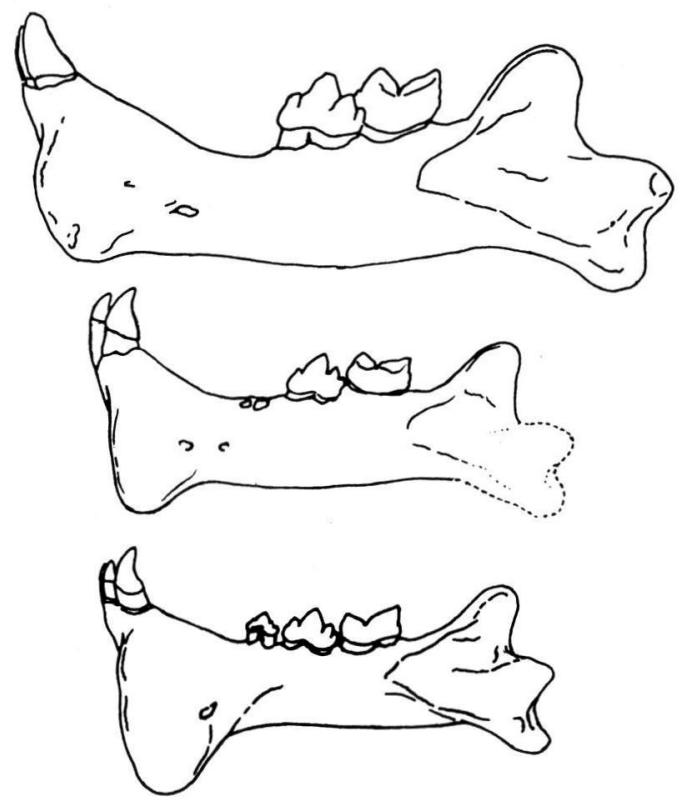

Fig. 2. Evolution of lower jaw and teeth in the Smilodontini. Bottom, Megantereon megantereon, Senèze, Villafranchian, with $\mathrm{P}_{3}$ and large jaw flange. Centre, Smilodon gracilis, Port Kennedy Cave, Yarmouth, retaining $\mathrm{P}_{3}$ (alveolus), flange somewhat reduced. Top, Smilodon neogaeus, Lapa Escrivania, Brazil, late Pampean, size greatly increased, $P_{3}$ lost, flange reduced. All to the same scale. 
populations may, however, be referred to a single evolving species, $M$. megantereon. At the close of the Villafranchian, the line became extinct in Europe, but in Asia (and Africa) it survived into the middle Pleistocene. The last representative of this line in Asia, known at present, is Megantereon inexpectatus from Locality 1 (the Peking Man site) of Choukoutien. The date of this form is late Elster or early Hoxnian. M. inexpectatus is larger than M.megantereon, showing that the phyletic growth continued, and in fact it is about the same size as the earliest American Smilodons.

Our next glimpse of this evolutionary line comes from the New World with the earliest known members of the genus Smilodon. They come from Port Kennedy Cave out of deposits that appear to be Yarmouth in age (HibBard, 1958). As fig. 2 shows, these forms resemble advanced Megantereon more than advanced Smilodon in many characters. They still retain a well developed $P_{3}$ (alveolus in the figured specimen) and have a distinct inner cusp (protocone) in the upper carnassial. On the other hand, the reduction of the dependent flange on the lower jaw has already got under way in the early Smilodon. The trend in this character, within Smilodon, shows well enough that the genus evolved from a large-flanged ancestor like Megantereon. Apparently the sabre still bit inside the lower lip in Megantereon, and had to have a sheath supported by the jawbone. In Smilodon the sabre bit outside of the lower lip, and the sheath could be reduced. If this character is made the key character of the two genera, the Port Kennedy Cave form should go into Smilodon in spite of numerous resemblances to Megantereon. The development of the jaw flange in the Choukoutien form is unfortunately unknown (TEILHARD, 1945).

In Smilodon of Illinoian age, from the Conard Fissure (Brown, 1908), further progress in size and dental characters have occurred, but not until Sangamon and Wisconsin time the full-fledged Smilodon known from Rancho La Brea and other asphalt deposits is met with.

It appears highly probable that the migration occurred at a point in time roughly coinciding with the age of the last known Megantereon. Thus the migration would be likely to be of Elster date. In this way it may be concluded that the characteristic Elster faunas of the Old World antedate the Yarmouth faunas in North America, and that the Yarmouth is a correlative of the European Holstein.

Smilodon also entered South America, where the earliest form, a relatively small and primitive one, occurs in the Chapadmalal (Kraglievich, 1948). This appears to give a maximum age for the Chapadmalal: it can hardly antedate the Yarmouth and Holstein.

The outlines of the evolution and migration of the Smilodontini are indicated in the diagram (table 1).

\section{B. Bears of the genus Ursus}

The bear family, Ursidae, is one of the smallest and most recent carnivore families. Three subfamilies are recognised at present (THENIUS, 1958, 1959), but one, the Agriotheriinae, became extinct at the close of the Pliocene, and does not concern us here. Another, the Tremarctinae, is exclusively American in distribution, and evolved from immigrants dating back to the Pliocene (Plionarctos). The presence of large tremarctine bears (Arctodus) may have been a factor in the relatively late spread of Ursus into the New World.

The third subfamily, the Ursinae, has a Holarctic and Indian distribution. With a single exception (Ursus americanus) all of its species are present in the Old World, and the fossil record shows that it originated in Eurasia. In the Nearctic, ursine bears are not known until the middle Pleistocene, with a single uncertain exception (Johnston \& SAvaGe, 1955), a specimen from the Blancan Cita Canyon; it is fragmentary and may, or may not, be ursine. 
Table 1

Evolution and migration of the Smilodontini

\begin{tabular}{|c|c|c|c|c|}
\hline South America & \multicolumn{2}{|c|}{ North America } & \multicolumn{2}{|r|}{ Eurasia } \\
\hline $\begin{array}{l}\text { Smilodon } \\
\text { neogaeus }\end{array}$ & Wisconsin & $\begin{array}{l}\text { Smilodon } \\
\text { "californicus" } \\
\text { (Rancho La Brea etc.) }\end{array}$ & Würm & \\
\hline \multirow{5}{*}{$\begin{array}{l}\text { Smilodon } \\
\text { ensenadensis } \\
\text { S. riggii } \\
\text { Chapadmalal } \\
\quad \uparrow \\
\quad-----\end{array}$} & Sangamon & $\begin{array}{l}\text { S. trinitiensis } \\
\text { Texas etc. }\end{array}$ & Eem & \\
\hline & Illinoian & $\begin{array}{l}\text { S. troglodytes } \\
\text { Conard Fissure }\end{array}$ & Riß-Saale & \\
\hline & Yarmouth & $\begin{array}{l}\text { S. gracilis } \\
\text { Port Kennedy Cave }\end{array}$ & Holstein & \\
\hline & & 1 & $\begin{array}{l}\text { Mindel- } \\
\text { Elster }\end{array}$ & $\begin{array}{l}\text { Megantereon } \\
\text { inexpectatus } \\
\text { Choukoutien }\end{array}$ \\
\hline & & & $\begin{array}{l}\text { Cromer } \\
\& \\
\text { Villa- } \\
\text { franchian }\end{array}$ & $\begin{array}{l}\text { Megantereon spp. } \\
\text { M. megantereon }\end{array}$ \\
\hline
\end{tabular}

Table 2

Intercontinental migrations of Ursus, excluding $U$.maritimus

\begin{tabular}{|c|c|c|c|c|c|}
\hline \multicolumn{3}{|c|}{ North America } & \multicolumn{3}{|c|}{ Eurasia } \\
\hline Recent & U. americanus & U. arctos & Recent & U. arctos & U.thibetanus \\
\hline Wisconsin & $\begin{array}{l}U \text {. americanus } \\
\text { Many locs. }\end{array}$ & $\begin{array}{l}U \text {. arctos } \leftarrow \\
\text { Alaska }\end{array}$ & $\begin{array}{l}---- \\
\text { Würm }\end{array}$ & $\begin{array}{l}U . \text { arctos } \\
\text { Many locs. }\end{array}$ & $\begin{array}{l}\text { U. thibetanus } \\
\text { China }\end{array}$ \\
\hline Sangamon & \multicolumn{2}{|c|}{$\begin{array}{l}\text { U. americanus } \\
\text { Trinity River }\end{array}$} & Eem & $\begin{array}{l}U . \text { arctos } \\
\text { Many locs. }\end{array}$ & $\begin{array}{l}\text { U.thibetanus } \\
\text { China }\end{array}$ \\
\hline Illinoian & \multicolumn{2}{|c|}{$\begin{array}{l}\text { U. americanus } \\
\text { Cumberland Cave, Conard } \\
\text { Fissure }\end{array}$} & Riß-Saale & $\begin{array}{l}U . \operatorname{arctos} \\
\text { Tornewton Cave } \\
\text { etc. }\end{array}$ & $\begin{array}{l}\text { U. thibetanus } \\
\text { Europe, China }\end{array}$ \\
\hline \multirow[t]{4}{*}{ Yarmouth } & \multirow{4}{*}{\multicolumn{2}{|c|}{$\begin{array}{c}U . \text { americanus } \\
\text { Port Kennedy Cave } \\
\uparrow \\
------\end{array}$}} & Holstein & $\begin{array}{l}U . \text { arctos } \\
\text { Grays etc. }\end{array}$ & $\begin{array}{l}U . \text { thibetanus } \\
\text { China }\end{array}$ \\
\hline & & & $\begin{array}{l}\text { Mindel- } \\
\text { Elster } \\
-----\end{array}$ & $\begin{array}{l}U . \operatorname{arctos} \\
\text { China } \\
------\end{array}$ & $\begin{array}{l}U \text {. thibetanus } \\
\text { China }\end{array}$ \\
\hline & & & Cromer & $\begin{array}{l}\text { U.thibe } \\
\text { China, E }\end{array}$ & $\begin{array}{l}\text { etanus } \\
\text { Europe }\end{array}$ \\
\hline & & & $\begin{array}{l}\text { Villa- } \\
\text { franchian }\end{array}$ & $\begin{array}{l}\text { U. etruscus } \\
\text { Europe }\end{array}$ & $\begin{array}{l}U . ? \text { ?thibetanus } \\
\text { China }\end{array}$ \\
\hline
\end{tabular}


The first certain ursine species to appear in North America is Ursus americanus, the black bear. The earliest record appears to be Port Kennedy Cave, as in the case of the smilodonts, and the bears evidently date from the Yarmouth. These early black bears are of moderate size and have several primitive characters, e.g. the large size of the upper carnassial and the small size of the last molar. In these characters, and also in morphology, the Port Kennedy Cave black bear closely resembles the middle Pleistocene Ursus thibetanus kokeni (Asiatic black bear) known from Chinese deposits, e. g. Choukoutien. It seems probable that the American form descended directly from the closely allied Asiatic species, and that the migration occurred at the same time as that of the Smilodontini, i. e. during the Elster Glaciation.

Illinoian black bears in North America, from Cumberland Cave and Conard Fissure (GIDley \& GAZIN, 1938), show definite advance over the stage seen at Port Kennedy. Late Pleistocene forms reached great size; in the Postglacial, the size was secondarily reduced (KURTÉN, in the press).

Two other species of Ursus are at present found in North America, the polar bears (Ursus maritimus) and the brown and grizzly bears (Ursus arctos). Both are conspecific with Old World species, and the indication is that their migration is of more recent date. Unfortunately the fossil history of the polar bear is practically unknown. As regards Ursus arctos, however, the fossil record bears out the contention. Most or all fossils of this species from North America appear to date from Postglacial times or possibly the latest Wisconsin (KuRTÉN, 1960). It is possible that the species was present in Alaska at a somewhat earlier date, well back in the Wisconsin. However this may be, the intercontinental migration evidently took place during the Würm $=$ Wisconsin. As a matter of fact, the morphology of the Alaskan and Eastern Siberian Ursus arctos indicates two independent migrations: a northern, with narrow-skulled animals from northern Siberia, and a southern, with broad-skulled animals from the Kamchatka population.

\section{The glutton, Gulogulo}

The glutton or wolverine evolved in the Old World. The ancestral form is the Cromerian Gulo schlosseri, known from various localities in Central Europe, and chiefly distinguished by its much smaller size. The first true Gulo gulo appear in the Elster (Mosbach; see Tobien, 1957) of Europe, and also in China (Choukoutien; see PeI, 1934).

In North America, the earliest record of wolverine appears to come from Cumberland Cave (GIDley \& GAzIN, 1938), where it is part of the cold elements that appear to date from the Illinoian (HrbBard, 1958). The Illinoian is thus the minimum age of the migration, but there is also a possibility that the migration dates back to the Elster. It may be noted, however, that the New World population is only very moderately differentiated from that in the Old (KURTÉN \& RAUSCH, 1959), and only ranks as a distinct subspecies. This would support a relatively late date, and at present a Saale-Illinoian migration appears the most likely alternative.

\section{Conclusions}

The three migration items discussed here support the correlation of glaciations and interglacials in North America and Europe as far back as the Holstein in Europe and Yarmouth in North America, as shown in tables 1 and 2. The exact European correlatives of the Kansan, the Aftonian, and the Nebraskan faunas remain doubtful. Perhaps the definitive clearing up of the migration of the elephants will settle part of the problem. The earliest true elephants in North America appear in faunas assigned to the Kansan, such as the Holloman and Cudahv ('TArlor \& HibBard. 1959). This early form is Elephas haroldcooki. Detailed analysis of a large material will be necessary to show whether 
this species may be derived from the primitive mammoths of the Elster, or from advanced Elephas meridionalis types of the late Villafranchian.

A correlation of the Kansan with the Elster would make the Aftonian a correlative of the Cromerian in Europe. The latter is a complex stage with two distinct temperate oscillations (WEST, 1961). On the other hand, many American specialists seem to favour a correlation of the Aftonian with the Villafranchian in Europe. Some implications of such a correlation are somewhat disturbing. Correlation of the Aftonian or part of it with the Villafranchian, and of the Yarmouth or part of it with the Holstein, would suggest one of the schemes (1)-(3) below, in contrast with the usual arrangement (4).

(1)

\begin{tabular}{l|l} 
Yarmouth & $\begin{array}{l}\text { Holstein } \\
\text { (Elster) } \\
\text { Cromer }\end{array}$ \\
Kansan & Günz \\
Aftonian & Villafranchian \\
Nebraskan & Donau \\
Rexroadian & Astian
\end{tabular}

(2)

$\begin{array}{lll}\text { Yarmouth } & \begin{array}{l}\text { Holstein } \\ \text { Kansan }\end{array} & \begin{array}{l}\text { Elster } \\ \text { (Cromer) } \\ \text { Günz } \\ \text { Aftonian }\end{array} \\ \text { Villafranchian } \\ \text { Rebraskan } & \text { Donau } \\ \text { Rexroadian } & \text { Astian }\end{array}$

(3)

$\begin{array}{ll}\text { Yarmouth } & \begin{array}{l}\text { Holstein } \\ \text { Kansan }\end{array} \\ \text { Elster } \\ \text { Aftonian } & \begin{array}{l}\text { Cromer } \\ \text { (Günz) } \\ \text { Villafranchian } \\ \text { Nebraskan }\end{array} \\ \begin{array}{l}\text { Donau } \\ \text { Rexroadian }\end{array} & \text { Astian }\end{array}$

(4)

$\begin{array}{ll}\text { Yarmouth } & \text { Holstein } \\ \text { Kansan } & \text { Elster } \\ \text { Aftonian } & \text { Cromer } \\ \text { Nebraskan } & \text { Günz } \\ \text { Rexroadian } & \text { Villafranchian }\end{array}$

It would obviously be premature to attempt an evaluation of these and other possible combinations at present, when even the intra-continental correlations (e.g., the dating of the American faunal sequence in terms of the American glacial-interglacial sequence) are somewhat uncertain. One possible source of bias in intercontinental correlation should, however, be mentioned. Strictly homotaxial relations for migrating groups can only be expected at the time of the actual migration, i. e., at the time of a glaciation, as a rule. Apparent homotaxial relations between interglacial faunas may be deceptive. For a hypothetical example, suppose that a typical Holsteinian Old World form migrates to North America in the Saale (Illinoian), and becomes extinct in Eurasia, or perhaps evolves into a more advanced Eemian type. If it is further supposed that the American immigrant happens to be known to us only in strata of Sangamon age, this will be a case of closer homotaxial relationships between the Sangamon and the Holstein, than between the Sangamon and the Eem. This may possibly have some bearing on the apparent relationship between the Aftonian and the Villafranchian. Naturally, migrants in the other direction, from the New World to the Old, will have the opposite effect; but as these migrations have been much less common, their effect is likely to be overshadowed.

Numerous migration items await detailed analysis. Lynxes among felids; wolf and red fox among canids; least weasel, otter and marten among mustelids are obvious cases in the Carnivora, and the only known American hyaenid may be added: Chasmaporthetes, which appears in the early Pleistocene Cita Canyon fauna and has a close relationship with the European Euryboas, the „sprinter hyena“. The importance of the Proboscidea has already been stressed, and numerous examples will be found among the rodents. Horses and camels exemplify migration from the New World to the Old, perhaps a subsequent remigration of modernized Equus into North America (McGrew, 1944). Elk 
(Alces), reindeer (Rangifer), yak (Bos), bison (Bison), musk ox (Ovibos) and sheep (Ovis) are important artiodactyl migrants from the Old World to the New, most of them in the late or latest Pleistocene.

\section{References}

Brown, Barnum: The Conard Fissure, a Pleistocene bone deposit in northern Arkansas: With description of two new genera and twenty new species of mammals. - Mem. American Mus. Nat. Hist. 9 (4), 157-208, New York 1908.

Gidlex, J. W., \& Gazin, C. L.: The Pleistocene vertebrate fauna from Cumberland Cave, Maryland. - Bull. U.S. Nat. Mus. 171, 1-99, Washington 1938.

Hibbard, Claude W.: Summary of North American Pleistocene mammalian local faunas. - Papers Michigan Acad. Sci. 43, 3-32, Ann Arbor 1958.

Johnston, C. S., \& SAvage, D. E.: A survey of various late Cenozoic vertebrate faunas of the Panhandle of Texas, part I: Introduction, description of localities, preliminary faunal lists. - Univ. California Publ. Geol. Sci. 31, 27-50, Berkeley 1955.

Kraglievich,Lucas Jorge: Smilodontidion riggii, n. gen. n. sp. Un nuevo y pequeño esmilodonte en la fauna pliocena de Chapadmalal. - Rev. Mus. Argentino Ci. Nat. 1, 1-44, Buenos Aires 1948.

KuRTÉN, Björn: A skull of the grizzly bear (Ursus arctos L.) from Pit 10, Rancho La Brea. - Los Angeles County Mus. Contr. Sci. 39, 1-7, Los Angeles 1960.

KuRTÉN, Björn \& RAUSCH, Robert: Biometric comparisons between North American and European mammals. - Acta Arctica 11, 1-44, Copenhagen 1959.

McGrew, Paul O.: An early Pleistocene (Blancan) fauna from Nebraska. - Geol. Ser. Field Mus. Nat. Hist. 9, 33-66, Chicago 1944.

Matthew, William D.: Critical observations upon Siwalik mammals. - Bull. American Mus. Nat. Hist. 56 (7), 437-500, New York 1929.

Meade, Grayson E.: The saber-toothed cat Dinobastis serus. - Bull. Texas Memor. Mus. 2, 25-60, Austin 1961.

PEI, Wen-chung: On the Carnivora from Locality 1 of Choukoutien. - Palaeont. Sinica, ser. C, 8, 1-216, Peking 1934.

Schaub, Samuel: Über die Osteologie von Machaerodus cultridens Cuvier. - Eclog. geol. Helv. 19, 255-266, Basel 1925.

TAYLOR, Dwight D. \& HibBard, Claude W.: Summary of Cenozoic geology and paleontology of Meade County area, southwestern Kansas and northwestern Ok!ahoma. - Pamphlet, 1-157, Ann Arbor 1959.

Teilhard de Chardin, Pierre: Les formes fossiles. - Les félidés de Chine, 5-35, Peking 1945.

THEnIUs, Erich: Über einen Kleinbären aus dem Pleistozän von Slovenien nebst Bemerkungen zur Phylogenese der plio-pleistozänen Kleinbären. - Razprave Slov. Akad. Znan. 4, 633-646, Ljubljana 1958. - - Ursidenphylogenese und Biostratigraphie. - Zeitschr. Säugetierk. 24, 78-84, Berlin 1959.

Tobien, Heinz: Cuon Hodg. und Gulo Frisch (Carnivora, Mammalia) aus den altpleistozänen Sanden von Mosbach bei Wiesbaden. - Acta Zool. Cracoviensia 2, 433-452, Kraków 1958.

West, R. G.: The glacial and interglacial deposits of Norfolk. - Trans. Norfolk \& Norwich Nat. Soc. 19, 365-375, Norwich 1961.

Manuskr. eingeg. 3. 1. 1963.

Anschrift des Verf.: Dr. B. Kurtén, Zoologisches Museum der Universität, N. Järnvägsgatan 13, Helsingfors, Finnland. 